\title{
'Order out of Chaos': resources, hazards and the production of a tin-mining economy in northern Nigeria in the early $20^{\text {th }}$ century
}

\begin{abstract}
This paper examines the development of commercial tin mining in northern Nigeria in the early $20^{\text {th }}$ century. It recounts how a fundamentally unknown space - an underground zone lying at the edge of Empire - came to be constructed as a mineral rich region, and subsequently integrated with capital and commodity markets in Europe as an extractive economy. From 1902 onwards, the landscape of the Jos Plateau was re-worked to supply tin ores and concentrates to smelters, refineries and fabricators in Europe. At their height, the mines of northern Nigeria provided almost one-tenth of the world's tin. The paper's primary aim is to problematize the processes of ordering and disordering that transformed the Plateau into an extractive economy. To this end, it examines geological science and colonial administration as practices that struggled to differentiate unfamiliar ecologies and invisible geologies into either resources to be exploited or hazards to be overcome. The paper illustrates the economic, political and cultural processes by which some conditions came to be seen as hazards (disease, seasonality of water supply, distance), while others were regarded as resources integral to the commerciality of mining on the Plateau (agricultural labour, land and water courses for sediment disposal, horizontal and vertical variation in ore grades). It shows how commercial exploitation of the Plateau's tin resources radically re-configured both physical landscapes and forms of social organisation on the Plateau, generating novel socionatural juxtapositions that came to be experienced as poor working conditions, environmental hazards, and conflicts between agriculture and mining over access to land.
\end{abstract}




\section{Introduction}

'The term of "White Man's Grave" as applied to Northern Nigeria is... absurd and entirely unjustifiable. West Africa today is probably, in every respect, safer to live in than India six years ago.'

\section{Governor Girouard (1908) Address to the African Society in London ${ }^{1}$}

'The fact that in little more than a decade British rule has reduced order out of chaos in Northern Nigeria, and has opened up a busy and promising tin field in a district which twelve years ago swarmed with hostile natives, is one upon which all concerned in the peaceful revolution have reason to be proud.'

Albert Frederick Calvert (1912) Nigeria and its Tin Fields ${ }^{2}$

Here two historical voices - one an instrument of British colonial government, the other intimately associated with share promotion in the City of London - tell a distinctive and familiar story about British involvement in West Africa in the early twentieth century. In this story a hostile and unruly landscape is subdued by the application of colonial administration, and then transformed through contact with the commercial logics of London-based investors and traders: order, in short, is 'reduced...out of chaos.' African landscapes - and African people - appear in this narrative as obstacles (to be) overcome, problematic phenomena whose submission to orderly technical description and political control marks the onset of modernity. A generation of post-colonial scholarship has convincingly deconstructed narratives like these as Eurocentric forms of knowledge integral to the exercise of colonial power and the expansion of capital: ways of knowing nature and place that effectively silence the voices, interests and agency of non-European peoples and license practices of dispossession. ${ }^{3}$ Although these engagements with colonial discourse have been enormously fruitful, the focus of this paper is on the actual practices by which nature and place came to be known and re-constituted by colonial and corporate interests at the turn of the last century. The declarations of economic, political and ecological transformation in the quotations above speak to the work involved in bringing commercial tin mining into being and sustaining it at the edge of Empire, notwithstanding their silences and apologetics. In taking this work of knowing and transforming nature seriously, the paper draws inspiration from Cole Harris' suggestion that it is in 'the ground workings of colonialism in colonized spaces around the world' that one can understand the ways in which colonial and corporate power achieves its effects (emphasis added). ${ }^{4}$

At the beginning of the twentieth century the high plateau region in the north-east of present day Nigeria was marked on British maps as a substantial blank. By 1912, however, Nigerian tin stocks were among the most actively traded in London and, a couple of years later, 50 companies and 18,000 labourers were mining or exploring for tin on what had become known as the Jos Plateau. By the 1920s the Plateau had been reconceived and reconfigured as one of the world's preeminent 'Tin Fields', a zone of mineralogical and commercial speculation that had caught the eye of European mining promoters, into which London-based investors would sink millions of pounds and that, at its height, supplied $10 \%$ of the industrial world's demand. Our primary objective in this paper is to problematize the process of 'producing' an extractive economy. To do this, the paper examines geological-geographical science and colonial 
administration as practices that struggled to differentiate unfamiliar social ecologies and invisible geologies and to put them together in ways that enabled commercial extraction. Drawing on corporate, government and personal archives, it illustrates the practices through which some conditions came to be regarded as hazards to be contained and overcome (disease, seasonality of water supply, distance), while others were regarded as resources integral to the commerciality of mining on the Plateau. It also shows how commercial exploitation of the Plateau's tin resources - which was continuous from 1904 until the cessation of large-scale commercial mining in the mid-1980s - radically re-configured both physical landscapes and forms of social organisation on the Plateau. While this 'modernisation' of geographical conditions enabled the opening of the Nigerian Tin Field, it also generated novel juxtapositions of people and environments that were experienced as threats to human health and increasing conflict between agriculture and mining over access to land.

Following this introduction, the paper is divided into five further sections. Sections 2 and 3 situate the advent of commercial production on the Jos Plateau against a backdrop of growing industrial demand for tin beginning in the late $19^{\text {th }}$ century. Sections 4 and 5 appropriate Calvert's conceptual twins of 'order' and 'chaos' to highlight the creative-destructive dialectic through which the geographical and socio-ecological conditions of northern Nigeria came to be transformed. Rather than use these terms to periodise history and measure progress (as Calvert did), we deploy them to signal our interest in practices of ordering/disordering space and nature. Section 4, then, examines the ways in which government and mining interests sought to rationalise the geographies and ecologies of northern Nigeria in the service of extraction, focussing in particular on disease, water and transportation. Section 5 shows how the expansion of mining also introduced new forms of disorder, creating its own 'chaos' as it re-worked prevailing socio-natural and socio-spatial conditions. Section 6 concludes the paper with a summary of its main findings.

\section{Modern Tin: the making of an 'erratic and exotic commodity',}

Tin is one of the seven 'metals of antiquity.' Valued for its low melting point, malleability and the ease with which it can be alloyed (in pewter and bronze, for example), it was used extensively in pre-modern times. ${ }^{6}$ But tin is also a quintessentially modern metal, part of a suite of "neo-technic" materials that proliferated from the end of the $19^{\text {th }}$ century following developments in metallurgy, electrical and telecommunication technology, the science of food preservation, and the development of a mass consumer market. ${ }^{7}$ Along with chrome, nickel, aluminium and the range of new materials being synthesised through organic chemistry, tin was a core material of what has come to be known as the 'second industrial revolution' based on electro-chemistry. ${ }^{8}$ From 1874 to 1910 the worldwide output of tin quadrupled and tin began to enter the households of Europe and North America in increasing quantities: alloyed with lead in solder and used as a coating for cables, tin sutured expanding electrical circuits and telephone networks; electro-plated onto steel, tin brought exotic foods into the home and transformed the experience of food preparation; rolled flat and formed into squeezable, collapsible tubes, it realised a desire for an increasing range of consumer products that competed for the disposable income of the middle classes; and alloyed into bearing metal, it lubricated many of the mobilities of modernity from automobile motor bearings to aviation applications. ${ }^{9}$ Tin also came to define the twentieth century experience on account of its many applications in armaments and the machinery of warfare. The industrialisation of warfare exemplified by the enormous consumption of munitions in the First World War and the sheer scale of military production worldwide - contributed to the dramatic surge in tin production 
and to a diversification of supply beyond the traditional mining regions of Cornwall (UK), New South Wales (Australia), and the Straits Settlements.

It is against this backdrop of tin's social proliferation and the industrialisation of warfare that the onset of industrial-scale, capital-intensive tin mining on the Jos Plateau has to be understood. As a tin-mining province, the plateau of Northern Nigeria came into being relatively late and on the heels of other new provinces in Australia and Bolivia in the last quarter of the $19^{\text {th }}$ century. Tin mining was part and parcel of the process of socio-ecological modernisation of northern Nigeria and the principal means by which the Plateau became incorporated into a world economy under conditions of colonial rule. ${ }^{10}$ Elsewhere in Nigeria the impetus of modernisation was missionary activity, anti-slavery campaigns, or palm oil, cotton, or rubber production. The relative topographical and historical isolation of the Plateau, however, meant that it was through tin that the creative-destructive energies of modernisation were transmitted to the edge of Empire.

\section{Tin mining comes to the Jos Plateau}

The Jos Plateau is an approximately L-shaped upland land mass in north-eastern Nigeria, occupying an area of over 2,500 square miles. ${ }^{11}$ Located between 3-4000 feet above sea level, the Plateau is a largely tree-less, undulating plain and the hydrographical centre of northern Nigeria (Figure 1). At the beginning of the twentieth century the plateau was occupied by people whom British officials referred to as 'pagans' on account of the fact that they were not Muslim and, therefore, unlike the Fulani who were dominant in the northern part of Nigeria. In many accounts from the late $19^{\text {th }}$ century and early $20^{\text {th }}$ century, the seeming impenetrability and resistance of the Plateau and its people to Fulani and European advances become fused into singular descriptions of a 'rocky fastness' ${ }^{12}$ Colonial geologists probing the interior of the newly acquired colonial Protectorate in the first few years of the twentieth century described a world their work would soon transform: 'the mysterious Bauchi plateau, the home of innumerable pagan tribes, whose precipitous walls on the south and west long marked the limit between the known and the unknown' ${ }^{13}$

Figure 1: Map showing location of the Jos Plateau and major features mentioned in the text

For Europeans the connection between tin and the Jos Plateau was made only at the end of the $19^{\text {th }}$ century. The United Africa Company - forerunner to the Royal Niger Company (RNC) found bundles of thin 'straws' of smelted tin available for exchange in its trading stations on the Benue River in the 1880s and, from the end of the decade, was purchasing these straws as part of its trading monopoly on the river. On the establishment of the Protectorate in 1900 the RNC became increasingly interested in exploiting the mining rights it had acquired as part of the agreement to cede its territory. The geographical imaginary in relation to minerals in this agreement is extensive: in the absence of geological surveys or mineralogical reports able to differentiate this large space into zones of more or less potential, the RNC protected its interests through an agreement that gave it "a half share of the mineral rights over a large area lying to the north of and between the Niger and Benue Rivers" for 99 years ${ }^{14}$. The royalty agreement drawn up between the RNC and the British Secretary of State for the Colonies marks a significant shift in the relation between Europeans and Plateau tin: the point at which mercantile relations based on the purchasing of tin are supplemented by rentier and extractive capitalism. Situated at the edge of a mercantile trading space based primarily on a network of navigable rivers, the need for a detailed knowledge of the socio-natures of the Plateau had been limited. Those seeking to invest in the mining of tin, however - and the fledgling 
government of the Protectorate seeking to encourage commercial activity to finance colonial administration - needed more specific, commercially-useful information about the location, areal extent, geological presentation (deep vs. shallow, alluvial vs. lode) and quality of tin on the Plateau.

After 1900 a series of publicly and privately funded expeditions explored the distant and underground spaces of the Protectorate and extended onto the Plateau. Initial work to locate tin was carried out under the auspices of private mining syndicates, although often with the assistance of government troops. First among these was an expedition led by George Nicolaus in 1902 and funded by the RNC. A mining engineer trained at the Camborne School of Mines in Cornwall and seasoned by experience in Western Australia, Nicolaus was employed to locate the source of the tin which the company had been trading. He travelled initially to Badiko where it was rumoured that tin had been mined but, finding there only a market for tin ore, he followed the trail of cassiterite to an area of mine workings in sands and gravels at the head of the Delimi River near Tilde Fulani. ${ }^{15}$ Nicolaus' expedition solved the question of tin's origins on the Plateau and effectively 'fixed' tin in space. The geographical resolution it provided both enabled the RNC to settle on boundaries for its application to the Protectorate for a grant of exclusive access and required it do so, given the competitive possibilities this new certainty had created. Through 'Exclusive License to Prospect, No.1 of 1902' - acquired under the Protectorate's first Mineral Proclamation, enacted earlier that year in response to the RNC expedition - the RNC obtained a temporary monopoly for prospecting over an area of 2916 square miles. A more extensive expedition was then organised from London to begin the mining of tin. Led by H. W. Laws - with 600 carriers and 25 Yoruba troops ${ }^{16}$ - this expedition established the first European mining camp on the Plateau at Naraguta on the Delimi in 1903.

Although the presence on the Plateau of the tin ore cassiterite in payable quantities had been quickly proven, capital was slow to follow. Mining promoters needed to demonstrate tin could be won in sufficient volume and at costs competitive with tin from the relatively low cost alluvial workings in Malaya and Indonesia. ${ }^{17}$ The high grade of Nigerian cassiterite, the extensity of the deposits, and the presence of ore close to the surface worked in the Plateau's favour as a source of tin for European industry. Some of the socio-ecological and spatial relations that characterised the Plateau, however, were extremely problematic and proved to be serious obstacles to the establishment of commerciality. Chief among these were the distance of the tin field from navigable waterways, the high cost of labour (for both porterage and mining), the dependence of production on seasonal rainfall for washing tin from sediments and, in the initial stages, persistent shortages of food and fuel. Thus it was that although the source of tin had been publicised as early as 1903, investors were slow to see the Plateau as an attractive space in which to chance their luck. While finance and skilled workers stampeded to other mineraliferous areas around the world, Nigerian tin languished as a geological curiosity. As late as 1909 the Niger Company was still the only company producing tin on the Plateau and annual output was less than 500 tons.

During the first decade of the Protectorate commercial promoters and colonial officials sought, sometimes with a note of desperation, to connect the occurrences of alluvial tin with the pool of investment capital available on the London Stock Exchange. The financial footing of the colonial state in Northern Nigeria was always precarious, and export-oriented enterprises like mining and plantation agriculture held for the state a prospect of revenue generation. ${ }^{18}$ Reports from mining engineers, mineral samples, and proofs of mining claims were ferried to London: these, triangulated via the mapping and survey work of the Imperial Institute and the universalising frameworks of geological science, mineralogy and economics, were used to 
generate estimates of size, value and potential profit. For many investors, however, the Plateau remained a zone of tremendous uncertainty when it came to profitability. Although its tin resources could be described and compared favourably with those observed elsewhere, many of the other conditions which bore on profitability were largely 'illegible. ${ }^{19}$ By the end of the decade, however, a number of other London-based syndicates had examined the tin ores of the Plateau. Among these, the interest of C.G. Lush appears to have been particularly significant. Initially with Champion Gold Reefs of West Africa, Lush's reports from Nigeria and his reputation in the capital as a tin expert - drove a rush to acquire exclusive control of the most prospective parts of the field. At Lush's suggestion, one of the company's directors Oliver Wethered, who was closely associated with the venerable Cornish tin mining concern at Dolcoath - had travelled to the RNC's Naraguta operation in 1908 and, on his return to England he bought the mine. This deal is credited with "precipitat(ing) the first Nigerian boom": ${ }^{20}$ Champion subsequently floated five Nigerian tin mining firms in London in 1909 and 1910, leading the Plateau's principal mining promoter to comment that the firm "has today, not merely one finger, but the whole of its digits in the Nigerian "pie", from which it has already pulled out a "plum" in the shape of a dividend of 100\% paid last March." ${ }^{21}$ This conspicuous bet on Nigerian tin drove speculative interest in London, and a brace of companies were floated in 1910 to mine on the Plateau. Figure 2 indicates the scope and scale of this speculative boom. It shows its strongly exploratory character: most licenses were for prospecting at this stage rather than mining and the field had yet to prove its commercial potential. It also shows the highly granular character of investment in this early boom: the standard pattern was the 'free standing firm' (Wilkins 1988) focussed on a single prospect and with relatively low levels of capitalisation ( $£ 50 \mathrm{k}$ to $£ 100,000 \mathrm{k}$ ), although overlapping directorships were common. By 1911, "some 200 prospectors were at work in Nigeria, often acting as agents for several firms at once.",22

\begin{tabular}{|c|c|c|c|}
\hline Company Name & $\begin{array}{c}\text { Number of } \\
\text { Exclusive } \\
\text { Prospecting } \\
\text { Licenses (1912) }\end{array}$ & $\begin{array}{c}\text { Number of Mining } \\
\text { Licenses (1912) }\end{array}$ & $\begin{array}{c}\text { Number of } \\
\text { Applications } \\
\text { Pending (1912) }\end{array}$ \\
\hline $\begin{array}{c}\text { Anglo- } \\
\text { Continental }\end{array}$ & 15 & 3 & 8 \\
\hline $\begin{array}{c}\text { Benue NN Tin } \\
\text { Mines }\end{array}$ & 13 & 1 & \\
\hline $\begin{array}{c}\text { Champion Tin } \\
\text { Fields }\end{array}$ & 8 & 1 & 6 \\
\hline $\begin{array}{c}\text { Kaduna } \\
\text { Syndicate }\end{array}$ & 6 & 7 & \\
\hline $\begin{array}{c}\text { Kano Nigeria } \\
\text { Tin Areas }\end{array}$ & 13 & 8 & \\
\hline Lucky Chance & 2 & 6 & \\
\hline $\begin{array}{c}\text { Naraguta } \\
\text { Extended }\end{array}$ & 21 & 3 & \\
\hline $\begin{array}{c}\text { Naraguta Tin } \\
\text { Mines }\end{array}$ & & & \\
\hline Niger Company & 21 & 1 & \\
\hline
\end{tabular}




\begin{tabular}{|c|c|c|c|}
\hline $\begin{array}{c}\text { Nigerian } \\
\text { Plateau }\end{array}$ & 2 & 7 & 12 \\
\hline $\begin{array}{c}\text { Nigerian Tin } \\
\text { Corporation }\end{array}$ & 9 & 17 & 3 \\
\hline $\begin{array}{c}\text { NN Bauchi Tin } \\
\text { Mines }\end{array}$ & 13 & 7 & 2 \\
\hline NN Trust; & 2 & 7 & 1 \\
\hline $\begin{array}{c}\text { Rayfield } \\
\text { Syndicate }\end{array}$ & 7 & 10 & 5 \\
\hline Sybu Syndicate & 10 & 1 & \\
\hline $\begin{array}{c}\text { Tin Areas of } \\
\text { Nigeria }\end{array}$ & 16 & 15 & \\
\hline $\begin{array}{c}\text { West African } \\
\text { Mines }\end{array}$ & 16 & & \\
\hline
\end{tabular}

Figure 2: Leading Holders of Prospecting and Mine Claims, Jos Plateau, 1912 Source: based on information in Langslow-Cock (1913) 'Map of the Nigerian Tin Fields'

By 1912, then, metropolitan capital had arrived on the Plateau. The competitive conditions of inter-capitalist rivalry under which it did so produced new geographies of claim ownership and strategic control. London's mining promoters had finally 'found' northern Nigeria's tin ores, a decade after they had first been definitively fixed to the Plateau by the RNC. But harnessing speculative capital to commodity production - the extraction and processing of tin for export - was to take a great deal of work over the next few years. As Freund (1981: 38) has pointed out, 200 companies may have invested $£ 10$ million in Nigerian tin in 1910 but the value of tin sold that year was only $£ 672,000$. Producing the conditions for profitable commodity production would require re-configuring both physical landscapes and forms of social organisation on the Plateau. Ultimately these efforts were successful: tin production rose 10-fold between 1909 and 1919, and doubled again by 1929 (Figure 3). However, the practices by which the Plateau was turned 'inside out' - as a mineral-rich space suitable for European financial speculation and commodity production - would generate new socionatural juxtapositions that came to be experienced as poor working conditions, environmental hazards, and conflicts between agriculture and mining over access to land. In the next sections we examine how capital and the colonial state - sometimes in alliance but at others in confrontation - sought to modernise socio-ecological and spatial relations on the Plateau. 


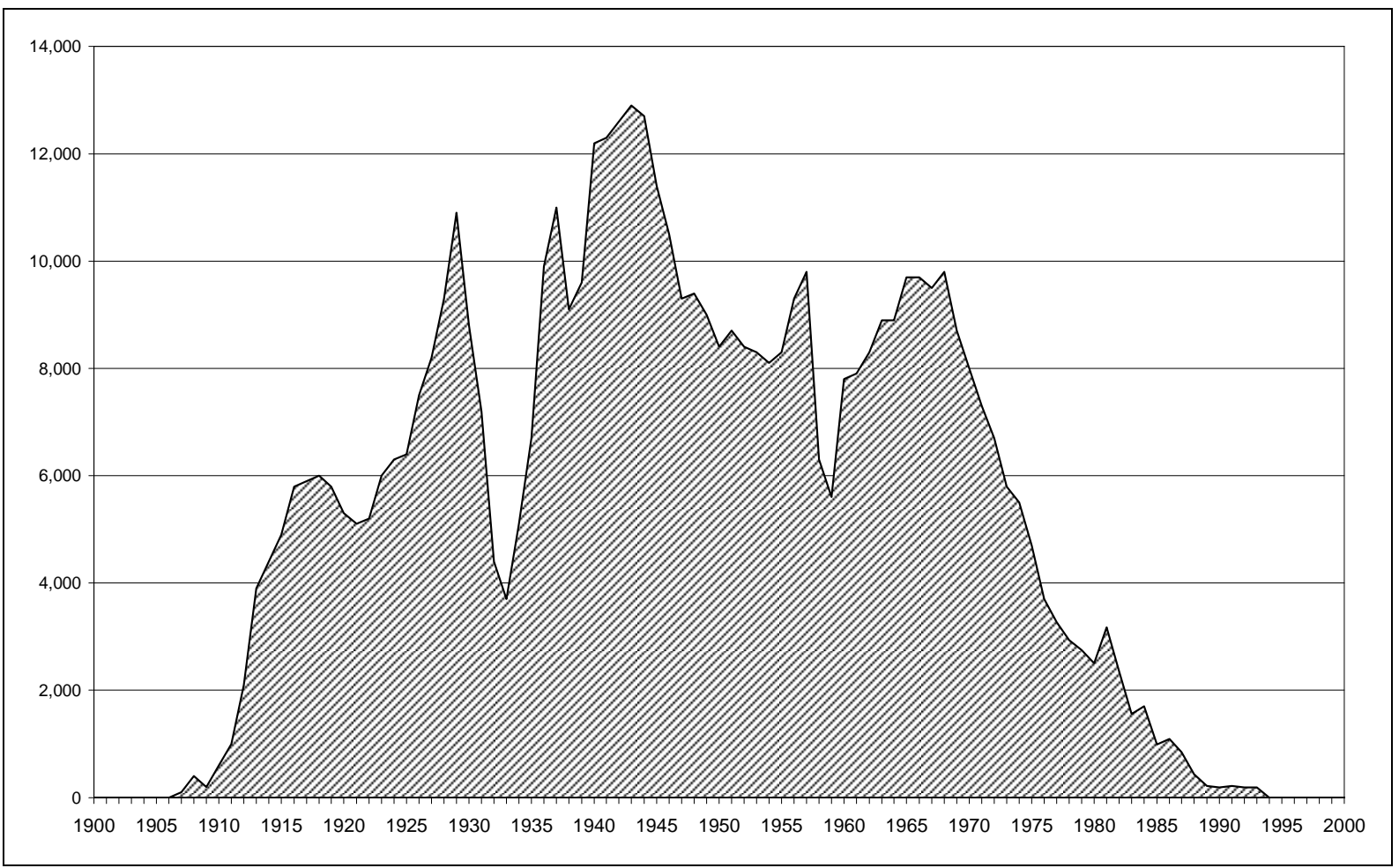

Figure 3: Mine Production of Tin (tons), Nigeria 1900-2000

Source: based on data in Schmitz (1979) and USGS Mineral Yearbooks (various years)

\section{Order from Chaos: hazard reduction and the rationalisation of space}

Recent work in critical political economy has illustrated how modernisation is a geographical project. ${ }^{23}$ Exemplified by historic practices of urbanisation or national-scale development in the late $19^{\text {th }}$ and early $20^{\text {th }}$ centuries, modernisation proceeds via the creative-destructive practices of re-working spatial and socio-natural relations. Here we show how, in transforming the Plateau into an extractive tin-mining economy, colonial and commercial agents confronted a range of geographical conditions that they considered hazardous to the lives and morality of Europeans, and to the commerciality of mining. In the initial phase of exploring for tin and establishing working mines, then, 'mining hazards' were the physical and social conditions which made commercial mining difficult on the Plateau and, accordingly, which made it harder for London-based promoters to raise finance to extract tin in Nigeria than for mining opportunities elsewhere. These were hazards to mining as perceived by engineers, surveyors and geologists in the employ of exploration and mining syndicates, by shareholders waiting for dividends that did not come, and by colonial administrators seeking to turn newly-acquired territory into productive estates. There was very little reference at this stage to the hazards of mine work for those who dug the pits, washed gravels or carried ore, and still less to the impacts of mining on livelihoods and land use on the Plateau.

The geographical conditions of the Plateau presented a series of obstacles to tin production that raised costs to the point that Nigerian tin was uncompetitive with tin from other sources, and which magnified the uncertainties of commercial investment. Among these conditions were the spatial distribution of resources in relation to a potential workforce, the presence of diseases to which Europeans had little resistance, the seasonal availability of water, and many of the practices and behaviours of people of the Plateau that were perceived as irrational and pre-modern. All were regarded as affronts to modernity, symptoms of an under-supply of 
science and/or a lack of disciplinary practices. Through the application of science and orderly administration such hazards could progressively be reduced and the 'natures' of the Plateau made serviceable for British commercial and administrative interests. Resource development was regarded as a central means by which the 'irrational' societies and uncertain ecologies of the Plateau would be tamed and made productive. For its promoters, mining represented a potent conjunction of science, technology and entrepreneurial capacity, a means for asserting control over apparently unruly and/or unproductive natures and their benighted peoples, and eliminating a dependence on the vicissitudes of nature. ${ }^{24}$

One of the great contradictions in their narrative of modernisation-via-mining, however, was that there was already mining on the Plateau: tin was being won from streams and smelted on the Plateau to produce the tin straws which the United Africa Company found traded on the Benue in the 1880s. This indigenous mining and smelting activity was well-established and formed a significant component of a pre-capitalist regional economy centred on the Sokoto Caliphate. ${ }^{25}$ Indeed many of the techniques and practices in use on the Plateau underpinned the success of early European mining ventures, not least because mine owners often let the right to work a particular patch of ground to 'tributors' and purchased from them any tin that was mined. ${ }^{26}$ The commercial challenge presented by an indigenous mining industry was effectively removed by outlawing indigenous ownership: the operation of a 'Restriction Scheme' that limited mine claim ownership to Europeans turned indigenous tin miners into 'pirates or thieves robbing the expatriates of their tin' and indigenous mining into another African 'tradition' that, like malaria and slavery, was to be extirpated. ${ }^{27}$ The potential ideological challenge presented by an indigenous tin mining and smelting industry was contained by stressing its anachronistic technological qualities and the inevitability of its decline in the face of more efficient European practices. In a letter to the company's Directors in March 1908, for example, an agent of the RNC, Walter Watts, noted that "if the natives.... with their primitive methods can reduce the tin ore to the extent of over 12 tons per annum of pure tin, with our cupolas we should be able to make a better showing, ${ }^{28}$

Gaining the upper hand over the Plateau required a rich geographical knowledge of its constituent parts, and a range of scientific-cum-military activities were arranged with the broad goal of improving the efficiency with which people, goods and capital could circulate through the Plateau. Geological and geographical surveys of new territories performed the critical task of extending 'the limits of dominion.... and accomplishing the steady reduction to 'law and order' of the provinces thus acquired'. ${ }^{29}$ For example, the Imperial Institute funded a major geographical and geological survey of Northern Nigeria between 1904 and 1909. Whereas the RNC-funded expeditions of Nicolaus and Laws had brought discrete patches of ground under intense surveillance, the Imperial Institute's surveys adopted a synoptic approach with the national territory as its frame of reference. Where the RNC and other companies probed the underground to determine the richest properties and calculate production costs, the colonial state aspired to a more ambitious epistemic grasp of the territory, one that sought forms of knowledge functional to administration and the production of social order. ${ }^{30}$ Five expeditions were carried out in total, each lasting an average of seven months. Led by J.D. Falconer, a geographer who was later to become head of the Nigeria Geological Survey, the surveys combined geological science and physical geography with a series of traveller's tales. The surveys were reported in the mining press and enthusiastically (and selectively) reproduced by mining share brokers. ${ }^{31}$ To read the survey reports is to see the colonial state struggling to make sense of a fundamentally unknown and often apparently aberrant landscape (the geomorphology of the Plateau, in particular, presented Falconer with a topsy-turvy world). Falconer and his team ferried to the field not only survey tools and 
instruments, but a set of taxonomic and categorical distinctions acquired through his training in England. Through a combination of observation, sampling and careful documentation, he differentiated the unfamiliar landscape of Northern Nigeria and inserted it into a temporal and spatial evolutionary schema. Once parsed in scientific terms, the landscapes of the Plateau could then pass into administration and rational planning. Practices of colonial science on the Plateau 'worked' by categorising and abstracting from the heterogeneity of socio-ecological conditions encountered, bracketing out certain types of variation while accentuating others. Hazards which received the greatest attention from the colonial state were those which threatened the 'productive' use of natural resources, including the productive use of European bodies. In Northern Nigeria, as in many other parts of Africa, it was the prevalence of disease, the (un)availability of water, and the distance and pace of transportation that most occupied colonial administrators and the early mining companies.

\section{Disease}

If geological and topographical mapping were among the primary practices by which the British sought to extend their administrative authority over the extensive spaces of the new Protectorate, so too were efforts to map, inventory and mitigate the impact of tropical diseases on Europeans. The effects of tropical climate on the European body and mind were a central concern that struck close to the colonial administration. One account indicates that 567 British colonial officials were 'invalided' by their tour in West Africa between 1911-1917: in Northern Nigeria alone 40 officials were invalided home in 1911, mainly for conditions related to climate. ${ }^{32}$ European death rates in Northern Nigeria were several times higher than in England and Wales, and exceeded those of lowland, humid Lagos (see Figure 4). The physical and moral deterioration brought on by tropical disease cut to the heart of the colonial project of re-configuring socio-natural relations along more rational, productive lines. Writing on Northern Nigeria, Geary describes the "weakening of the control of the brain which results in outbursts of tropical fury.... Honourable men, with the weakening of mental control, will do what would be unthinkable to the same persons in the temperate climates. European women often suffer from nymphomania. ${ }^{33}$ The reality was more prosaic: around $25 \%$ of European deaths were related to malaria, with blackwater fever, dysentery and yellow fever accounting for many of the rest. ${ }^{34}$

\begin{tabular}{cccccc} 
Year & $\begin{array}{c}\text { European } \\
\text { Population }\end{array}$ & Deaths & $\begin{array}{c}\text { Death Rate } \\
\text { (per 1000) }\end{array}$ & Invalids & $\begin{array}{c}\text { Invaliding Rate } \\
\text { (per 1000) }\end{array}$ \\
\hline 1903 & 309 & 18 & 58.25 & 43 & 139.15 \\
1904 & 322 & 13 & 40.37 & 67 & 208.15 \\
1905 & 342 & 10 & 20.23 & 40 & 143.27 \\
1906 & 347 & 17 & 48 & 55 & 158.5 \\
1907 & 424 & 7 & 16.5 & 50 & 117.92 \\
1908 & 499 & 10 & 20.04 & 48 & 96.19 \\
1909 & 544 & 13 & 23.8 & 67 & 123.16 \\
1910 & 637 & 13 & 20.41 & 48 & 75.35 \\
1911 & 641 & 13 & 20.28 & 40 & 108.4 \\
1912 & 703 & 22 & 31.29 & 50 & 124.12
\end{tabular}

Figure 4: European Deaths and Invaliding Rates, 1903-1912

Marking out spaces of health and disease - and seeking to extend the former while shrinking the latter - was central to the colonial project of administering northern Nigeria, and 
underpinned efforts to attract European management to the mines on the Plateau. Official discourse abounded with efforts to distinguish the Plateau as healthful in comparison with the humid, lowland tropics, with the Plateau's climate and elevation portrayed as an almostEuropean like space. ${ }^{36}$ Colonial concerns about disease rarely extended to the indigenous population in this early period (data on disease rates among African officials were collected for the first time in 1912). The African population and customary practices (concerning the proximity of crops to houses, or sanitation, for example) were regarded as contributing to the prevalence in Europeans of diseases like malaria, blackwater fever and dysentery. The Plateau population were encouraged to follow the European practice of cutting grass and brush close to houses and, where these were unsuccessful, policies of residential segregation were proposed to combat malaria. ${ }^{37}$

The lack of attention to the health of the indigenous population demonstrates both a naturalisation of African health and death (except where these intruded on the health of Europeans), and a failure to recognise - still less to address - the momentous changes in livelihoods occurring on the Plateau in association with the onset of large-scale tin mining. A brief comment in the Protectorate's Health Report for 1912 notes that difficulty of obtaining health statistics on mining communities and proposes the introduction of a 'system of returns of sickness' to monitor 'this rapidly increasing class of individuals'. ${ }^{38}$ However, the extensive recruitment of labour from the Yoruba and Hausa settlements off the Plateau - to work in the mines and to carry out the vital work of porterage - significantly changed the distribution and density of population on the Plateau. The influx of population, combined with a colonial taxation policy - that required farmers to devote land to cash crops or to sell their labour for cash rather than growing food - drove agricultural and land use changes that significantly impacted the health and livelihoods of people on the Plateau and contributed to the prevalence of disease. In 1911-13 taxation-driven changes in land use combined with poor rainfall ${ }^{39}$ and a substantially-increased population to produce 'near famine' conditions at the mines. ${ }^{40}$ Events like these were understood primarily, however, via the calculus of chance - that is, as a function of the unpredictable and unruly character of climate and people - rather than as hazards that originated in the social and socio-ecological relations introduced to support commercial mining and which had their effects on the lives and livelihoods of Africans.

\section{Water: the 'lifeblood of alluvial propositions'}

'...insufficiency of water has presented serious difficulties and, in spite of careful methods of conserving the supplies, it still remains the most difficult mining problem in the country, with the result that the production of many mines fluctuates greatly in proportion to the amount of water available at different periods of the year. ${ }^{41}$

Tin mining in its early years was completely dependent on the availability of water, since flowing water provided the primary means for sorting tin from other sediments. The traditional approach of calabashing (or panning) in streams relied on in-stream water flows, and the scaling up in production associated with the entry of European firms after 1908 significantly increased demand for water. Picks, shovels and basic construction equipment meant that mining was no longer confined to stream beds, but extended to sands and gravels alongside the stream and even to patches of gravel at some remove. Diversion and extraction of water for mining increased accordingly. The streams and rivers running off the Plateau frequently failed in the dry season and, as a consequence, mining was restricted at many operations to the eight months or so outside the dry season. It was common as late as 1919, 
for example, for firms to undertake ground sluicing and stripping operations during the rains and to use hand labour and sluice boxes in the dry season. ${ }^{42}$ Shortages of water limited the ability of individual mines to expand and, for some of the lower grade deposits, restricted their ability to achieve the economies of scale necessary to be profitable. Seasonal fluctuations in supplies of water and labour were "always an irritating handicap in the successful exploitation by hand methods, and in fact was often a deciding factor in the success or failure of what was otherwise a payable deposit". ${ }^{43}$ In many respects, then, European tin mining had a decidedly pre-modern character that belied its self-identification as the leading edge of socio-economic modernisation.

Mining firms and the colonial government sought ways to rationalize the distribution of water. Dam building, pipelines and extensive leat construction collected, concentrated and directed the flow of water towards mining operations and modified its seasonal availability. During the dry season in 1919, for example, Naraguta mines constructed a leat system covering eight and a half miles that increased both the working time and spatial scale over which the alluvial deposits could be worked by hydraulic means. ${ }^{44}$ Other companies acted similarly: for example, Ropp developed 18 miles of leats to expand its hydraulic plant at this time, and Bisichi constructed a dam on the river Fusa and piped water to its operations. ${ }^{45}$ Despite the scale of these efforts and their replication across the tin field, water diversion schemes did not fully remove the hazard of seasonal rains which continued to adversely affect output of tin until the introduction of electrical power after 1916. Electrical power drove a step-change in the technical conditions of mining on the Plateau. It reduced the need for water to move and sort gravels, was employed to recycle and pump water from the tail races, and enabled firms to realise economies of scale. Significant hydro-power schemes were developed in the 1920 s at Kwall and Kurra - on the north and south ends of the Tin Field respectively - enabling production year round. ${ }^{46}$

\section{Transportation}

The development of commercial mining on the Plateau relied as much on reducing the 'friction of distance' on the Plateau (and Northern Nigeria more generally) as it did on securing the location of minerals. For the value of tin ores to be realized, spatial and social relations had to be produced on the Plateau that enabled supplies to flow in and smelted tin and ore to move out. The difficulty but also the security of travel to, from and on the Plateau proved a major obstacle to the development of a Tin Field. Expeditions to search for and extract tin were resisted by populations on the Plateau, with surveyors reporting that 'prospecting was made practically impossible owning to the hostility of the native tribes' ${ }^{47}$ In 1902 the first Royal Niger Company expedition to the Plateau 'subdued' the Emir of Bauchi with the assistance of the colonial government's political agent (Sir) William Wallace. The Emir's capture enabled the expedition to reach the Delimi River from where 'tin sands, the first ever seen or procured by Europeans' were brought to London. ${ }^{48}$ The following year Law's mining expedition employed 600 porters and the weaponry and services of 25 members of the Second Battalion, Nigerian Regiment to expand the area in which prospecting could be carried out. Laws took up arms frequently as he explored the extensity of the tin deposits, secured ground, and sought to establish a short cut over the Plateau that "was badly needed for transport purposes.' Attempting to cross lands of the Ganawarri people, he called on the colonial authorities for support. A 'company of the $1^{\text {st }}$ Battalion with a machine gun and three officers' were provided and the expedition fought its way through: Laws records that 'with the machine gun and a hundred rifles, the affair did not last long'. ${ }^{49}$ These violent, destructive encounters are a valuable corrective to overly 'epistemological' accounts of 
colonial rule that would have commercial tin mining arrive on the Plateau solely via the creative rationalities and metrics of geology, economics, and law.

Indeed, securing transportation routes and improving the speed and certainty of communication were central to the colonial state's modernisation of social relations on the Plateau. The cost of transportation was a major obstacle: in 1909 it cost as much (£25) to move a minor official across northern Nigeria from Zaria to Kano as it did to travel from Liverpool to Lagos. ${ }^{50}$ In the early period these improvements centred not on introduction of technology, but on organising human porterage on a massive scale: in 1911, for example, 35,000 people were employed to carry mining and food supplies up onto the Plateau and carry out tin and concentrates, a 12 day walk covering 200 miles from the Plateau mines to Loko on the Benue River. ${ }^{51}$ Experiments with donkeys and bullocks failed and human porters provided the core transportation force until around the First World War. Efforts to modernise this method of transportation centred on improving efficiency and reducing costs which compared unfavourably with those in the Straits Settlements. ${ }^{52}$ The arrival of the railway at Zaria in 1912 - and completion of a narrow gauge extension to the Tin Field by 1915 (Figure 1) significantly shortened the distance over which supplies and tin had to be carried. Rail transport reduced the expense of moving tin to the coast from $£ 2910$ s per ton (via human porterage and river transport in 1908) to $£ 8$ and enabled large-scale equipment to be brought to the Plateau. ${ }^{53}$ Dredges, gravel pumps, hydraulic monitors, drag line excavators and drills arrived on the Plateau from 1915 onwards, enabling firms to expand their operations laterally to lower-grade ore deposits and vertically to access deeper deposits. In this way the modernisation of spatial relations enabled social and environmental conditions to be transformed with increasing intensity: mines increased in size, the area under claims expanded in a 'new burst of energy' associated with 'systematic prospecting of the deeper deposits by drilling,' competition to control key water-power sites reached new heights, and the volume of tailings and wastes increased. ${ }^{54}$

By the late 1920s, with tin production rapidly increasing, the work of corralling the unruly natures of the Plateau appeared to have been completed. Its complex geomorphology and socio-ecologies had been tamed, brought under colonial administration and re-fashioned in the service of commercial gain. The Plateau boasted power stations, an electricity distribution system, an urban population, and the largest mine labour force north of the Limpopo. ${ }^{55}$ Commentaries from the period emphasize the extensive re-working of spatial and socioecological relations on the Plateau, and the rapid modernisation and incorporation into the world system of a space which, only thirty years before, had been for Europeans a terra incognita at the edge of empire.

\section{Chaos from Order: mining expansion and the creation of hazard}

The previous section has shown how the advent of commercial tin mining on the Plateau was a product of much more than geological exploration and an act of 'discovery:' it rested on practices which differentiated, quantified and delineated resources and hazards, and which sought progressively to modify and transform geographical and socio-ecological conditions that were not conducive to commercial scale production. By many measures these practices were extraordinarily successful: tin production in Nigeria expanded rapidly in the second decade of the twentieth century, the number of firms mining for tin on the Plateau increased, and Nigerian tin became a regular staple of tin imports to the UK. However, to view the 'coming of tin' as a conquest - a transformation of socio-ecological conditions that eliminated hazard unambiguously - is problematic. The finality of the term 'conquest' does not express 
the contradictory nature of the socio-ecological relations produced on the Plateau as the space was reconfigured for commercial tin mining (although it does more satisfactorily describe the violent dispossession and overwhelming asymmetries of force through which commercial mining was introduced). As tin mining activity expanded, it produced novel juxtapositions of people and resources - i.e. new socio-ecological relations - that came to be experienced by those living and working on the Plateau as hazards to health and livelihoods.

\section{Working conditions}

In the UK the occupational hazards of mining had come slowly and sporadically under statutory legislation during the last quarter of the $19^{\text {th }}$ century. ${ }^{56}$ UK legislation on worker health and safety, however, did not extend to early British investments in Nigerian tin. The fact that regulations governing conditions of work in mines in the UK were not replicated for mines in northern Nigeria is certainly consistent with the absence of medical scientists from the Plateau in the initial years of expansion, the different mandate of 'Mines Inspectors' in the UK and in the Protectorate, and general attitudes towards the welfare of African labour. It also, however, reflects the different character of tin mining in Cornwall and Nigeria: whereas Cornish mining after 1870 utilised dynamite and rock drills on hard-rock deep underground, most tin mining in Nigeria had a lower technological intensity and was associated with the surface digging and washing of alluvial gravels in open pits. The occupational hazards associated with these contrasting modes of extraction were different: the health and safety issues which surrounded UK metal mining in the early twentieth century - rock dust, poor ventilation and the prevalence of lung disease - were largely irrelevant to alluvial mining. ${ }^{57}$

Overall, however, it appears that working conditions in the mines were harsh. The mines used forced and conscripted labour from time to time: tin miners shifting supplies across the Plateau were noted to have 'marched with revolvers drawn to get the carriers to stick it out'. The worst abuses fell foul of the Colonial Administration: in 1906, for example, the Local Resident stepped in to remind the local population that they did not have to work in the mines. ${ }^{59}$ The written record contains little information about the health of the working population in the mines beyond an annual tally of the accidental deaths. It appears, however, as if death rates were far in excess of those of the European population: one account indicates the death rate at the Jemaa Tin Mines to be an astonishing 285 per 1000 per year. ${ }^{60}$ This suggests that health and sanitation were significantly greater killers than accidents associated with mine working which were caused predominantly by earth falls: official data indicate 16 deaths and 12 injuries in 1916 across all the mines. ${ }^{61}$ Colonial reports comment regularly on the lack of sufficient supervision of workers by mine management. Limited oversight was a direct consequence of trying to reduce the high cost of sustaining a European workforce on the Plateau: at Consolidated Gold Fields' operations in 1910, for example, the European workforce consisted of a handful of men but represented $55 \%$ of wage costs. ${ }^{62}$ Although the first safety legislation was introduced by the Colonial Government in 1917 - covering machinery, use of explosives, open cast workings and underground working - the impact of this legislation on working conditions appears to have been limited.

Large numbers of people were recruited to work the mines, and between 1910 and 1950 the population of the Plateau rose to around half a million. Sharply increased population densities in the Tin Field contributed to a variety of sanitation and health issues associated with the use of water and other local resources. Historical evidence relating to sanitation conditions on the Plateau is limited. However, an account of deteriorating river water quality associated with gangs of railway construction workers upstream of Zungeru (off the Plateau) provides an 
indication of the sort of problems with which an influx of workers onto the Plateau would have been associated. Officials fulminated against the loss of water quality, set up a 'daily issue of condensed water to all Government clerks' and proposed measures to 'combat this evil'. ${ }^{63}$ The density of population created by the influx of mining contributed to the spread of diseases: a report on the influenza pandemic of 1918 - which arrived in Nigeria in September and was largely over by February 1919 - notes how the malady 'made its way steadily along the thoroughfares, railways, rivers, trade routes and roads... (and) took a particularly heavy toll in the densely populated pagan centres' including those on the Plateau. ${ }^{64}$

\section{Producing environmental hazards}

In their efforts to remain competitive, tin mining firms structured social-ecological relations in ways that displaced - socially, geographically and temporally - many of the potential costs of winning tin. As production increased and the mined area expanded in the first half of the twentieth century, working practices that drew inputs (such as fuel and water) from the immediate locality or which relied on the capacity of the local environment to absorb or accumulate process wastes began to create significant social and environmental hazards. After eighty years of tin mining the Plateau had an estimated 316 square kilometres of degraded lands - approximately $4 \%$ of the surface - with most of this concentrated along the Jos-Ropp axis at the centre of the field. ${ }^{65}$ Efforts to rehabilitate this area would later lead to its designation by the Plateau State Government as a 'disaster zone' in 1982 as part of a broader strategy to secure Federal funds to carry out the work.

Soil erosion, brush cutting, and the sterilisation of agricultural land generated significant hazards for the agricultural population of the Plateau. The first Plateau ecologies to feel the pressures of extractive capitalism were the scattered patches of trees and brush and 'the only trees left standing on the Plateau were those which refused to burn. ${ }^{66}$ Brush was used as fuel for a variety of purposes, with some feeding the smelting works erected at Naraguta by Laws in 1904 in an effort to overcome the high costs of transporting tin ore off the Plateau. The expansion of mining activities over time produced several 'pulses' of land-use change. The first occurred with the rapid increase in the number of mines and the geographical extent of mining after 1910. The process of stripping the alluvial blanket and extracting from it a relatively small amount of tin - estimates suggest that on average 1 cubic yard of material was moved to recover $3 / 4 \mathrm{lb}$ of tin - resulted in a need to dispose large volumes of waste material or tailings. In many cases tailings were allowed to flow onto surrounding land. The use of surface land for mine waste disposal emerged as one of the most politically contentious aspects of mining in the early years. Concerned at the unrest it could create, the British Resident intervened at times to protect the interests of farmers whose lands and crops were being utilised by miners. Indeed, the propensity of tin mining to disrupt the social relations of agriculture, politicize agriculturalists and, at the extreme, threaten the legitimacy of colonial rule was one of the main issues dividing European plantation and mining interests in Nigeria. ${ }^{67}$ The Mining Ordinance of 1916 - coming into force just as firms were scaling up their operations - designated all rivers as 'sludge channels' into which tailings could be disposed. By this practice firms avoided paying the cost of holding land and/or building structures to impound tailings, and passed the costs of tailing disposal - in the form of blocked river channels, increased flood risk, and depleted aquatic health - downstream.

After the First World War, when mines began to employ more capital-intensive modes of extraction, the volume of earth material excavated and dumped in mounds and stream beds much increased. By 1920 pick and shovel methods had been supplemented by dredges, 
draglines, water-monitors, and excavators. These expanded the area under mining and enabled deeper deposits up to 10 metres below the surface to be worked. ${ }^{68}$ Shifts in technologies of extraction 'heralded the start of major landscape changes' because they enabled miners to expand beyond contemporary river channels to work more extensive paleochannel deposits buried beneath the surface. The introduction of draglines in 1924 was particularly significant in changing surface topography. Because deeper deposits took the narrow, sinuous form of a former river channel rather than an extensive layer, conventional 'cut and fill' methods of dragline operation were impractical. To work the buried rivers, draglines progressed along the channels producing a landscape of steep mounds that bordered vertically-sided and often very deep 'paddocks'. Up to 30 metres deep in places, paddocks rapidly flooded once mining ceased. ${ }^{69}$

\section{Mining hazards as sites of social conflict}

For mining companies, the ability to source water from the surrounding environment, to secure local food supplies, and to dispose of mine wastes on non-mining land were essential practices which underpinned their balance sheets. As the area of land claimed for mining rapidly expanded, so teams of surveyors from the Colonial Survey Department were increasingly called upon to establish the boundaries of licenses and claims. The new and complex administrative landscapes they produced (literally) overlay the scientific landscapes produced through geological and geographical surveys. Fixing tin in legal and administrative terms was no easy matter. The patchwork landscape of claims and licenses reveal not only the straight lines of Cartesian cartography and property law, but also the rampant competition, gamesmanship and outright skulduggery used to acquire the best land. And the more precise the geographical resolution sought - to peg out the boundary between rival claims, for example - the more the hoped for certainty appeared to slip away (by exposing, for example, the uncertain location of beacons from which land measurements were initially taken). During the run-up to the first mining boom, the challenge became so great that Governor Hesketh Bell threw up his hands and declared himself incompetent for the highly technical task of revising the Protectorate's Mining Ordinance. The demand for licenses for minerals, water rights and power sources had outstripped the Protectorate's capacity to provide them, and Bell appealed to the Secretary of the State for the Colonies to provide him with a technical officer with knowledge and experience of mining booms in other territories. ${ }^{70}$

But the potential for tensions between mining interests and the colonial state were not limited to technical matters and the need for a skilled administrative cadre. As mining expanded it quickly became associated with tree loss, soil erosion, and degraded agricultural lands. As these 'negative externalities' of mining - the costs arising from mining practices which fell not on mining companies but on other land users - accumulated they emerged as the focal point for struggles between mining firms and agriculturalists. The growing administrative authority of the colonial state was increasingly called upon to settle these disputes. The Colonial Resident at Bauchi, for example, stepped in to stop practices of waste disposal at the mines that were deemed to run counter to the colonial state's mandate and interests. ${ }^{71}$ While intervention did reflect a concern on the part of the colonial state for the welfare of agriculturalists, it also expressed a division within the colonial elite between mining and other commercial interests (e.g. plantation agriculture). To non-mining concerns, the social and environmental dislocations caused by mining - such as soil erosion, loss of agricultural land, and the distorting effects of a large mine labour force on local food and labour markets ${ }^{72}$ could create conditions of social disruption and political instability that undermined the productivity of labour (and, in the extreme, colonial rule). The success of commercial tin mining and its rapid expansion, then, produced a series of social and environmental hazards 
that became focal points for opposition to the activities of tin mining companies and called into question the legitimacy of tin mining as an activity consistent with colonial goals.

At the creation of the Protectorate the fledgling colonial state had applied an armoury of metrics and visualisation devices to map, quantify and administer its newly- acquired lands and resources. ${ }^{73}$ By the mid-1920s these metrics were being turned towards mapping, quantifying and administering hazards arising from the 'modernisation' of socio-ecological and spatial relations on the Plateau. Soil erosion, land sterilisation, and silted streams and rivers were in large part a product of practices adopted by mining companies to reduce the micro-economic costs of tin production. Understanding these hazards, mapping their distribution, and transforming them - to minimize their negative impacts or convert them into new resources - were tasks that the colonial state increasingly absorbed as part of its administrative mandate. In the 1940s, for example, the Plateau Provincial Development Committee reported on the causes of soil erosion. In 1947, the Governor of the Eastern Region of Nigeria sought advice on the cause of large gullies in the Udi escarpment. Following an approach to the Royal Geographical Society, a Cambridge geography graduate A T Grove - was appointed to report on soil erosion in the Eastern Region and on the Jos Plateau and the Mambilla Plateau. This appointment led to a detailed regional survey with the aid of aerial photography that mapped and quantified the extent of soil erosion on the Plateau and its association with mining activities. ${ }^{74}$ In these surveys the density and distribution of population on the Plateau - a direct product of the labour regime instituted by the mines emerge as a central concern of government. As elsewhere in West Africa, Plateau ecologies came to be described via narratives of crisis in the relationship between human and livestock populations and resources. $^{75}$

By the 1940s the colonial government had introduced licensing to control cattle numbers and ordinances on bush burning, constructed contour bunds, set up of forest reserves, and proposed an extensive terracing programme covering over a million acres. Elsewhere in northern Nigeria groundwater resource development via a government-funded programme of well-drilling was begun in an effort to redistribute the agricultural population. ${ }^{76}$ On the Plateau the 'practically uninhabited country' to the southwest (the Shenham District) was found to be 'capable of absorbing the surplus population' and developed for a resettlement scheme. ${ }^{77}$ With conditions on the Plateau re-framed as a crisis of food availability in relation to population, the landscapes and ecologies produced by mining were appraised for the potential role they could play in furthering agricultural development and alleviating the pressure of population on resources. The paddocks, gullies and dams produced by mining, for example, were identified as valuable reservoirs, stock ponds, and ideal environments in which to produce fish. Paddocks, in particular, were endorsed as a means of supplying fish and improving nutrition: a key report on soil erosion noted enthusiastically how 'even now, numerous fish are caught in [the paddocks] and there is a great need for additional protein in the Pagan diet'. ${ }^{78}$ These examples indicate an increasingly 'developmental' colonial state intervening directly to (re)produce environmental conditions for agricultural development on the Plateau, many of which had been undermined by commercial tin production. ${ }^{79}$ The 1946 Minerals Act, for example, required the state to restore the productive utility of mined lands for agriculture: while firms were responsible for removing and stacking topsoil and draining open cast workings, it was the responsibility of government to replace topsoil and carry out 'all further measures to restore fertility to the land' ${ }^{80}$ The capacity of the state to undertake this work was severely constrained, however, and by 1990 only $1 \%$ (around three square kilometres) of the area degraded by mining had been formally restored. ${ }^{81}$ By contrast, the informal reclamation strategies adopted by area farmers have been relatively successful at managing soil fertility at abandoned mine workings on the Plateau. ${ }^{82}$ 
The availability of new scientific techniques has led more recently to a further round of appraising, quantifying and mapping the waste products of tin mining. Investigations in the late 1990s indicate elevated levels of naturally-occurring radioactive materials in parts of the tin field that have been mobilised and concentrated by historic mining activity. Tailings containing uranium and thorium have subsequently been dispersed among the population via their use as building materials, while contaminated soils and water supplies are used for crop production. It appears to be 'occupational farmers and mostly illegal cassiterite and columbite miners' who are most affected. ${ }^{83}$ The paddocks viewed in the pre-independence era as promising resources for increasing agricultural output and protein availability in the context of concerns about population pressure, are now re-imagined as hazardous conduits through which radionuclides accumulate in the bodies of the poor.

\section{Conclusion}

In this paper we have shown how a remote space largely unknown to Europeans was transformed into an extractive economy in a relatively short space of time. Our approach has been to examine some of the practices through which underground spaces in northern Nigeria became an object of financial speculation and investment, connecting the Plateau to financiers in the City of London and to growing industrial, domestic and military markets for tin. Our argument is that the Jos Plateau did not become a 'Tin Field' through a simple act of mineral discovery. On the contrary, producing it as a zone of commercial opportunity that compared favourably with other tin-producing regions around the world took a good deal of work. It rested on the reconfiguration of landscapes and livelihoods, interventions in the socioecologies of the Plateau that were as epistemological as they were material. Our focus in this paper has been on the practices through which 'nature' was differentiated into resources and hazards. The existence of the Plateau as a 'Tin Field' was achieved by stabilizing resources and hazards as meaningful entities (via recourse to frameworks of science and metrological devices that enabled comparison), giving them a geographical expression that fixed resources and hazards in the landscape, and then working to redefine these boundaries in ways that made tin mining a commercial proposition. We have shown how these practices were associated not only with the introduction of tin mining, but were on-going: the expansion of mining in the second and third decades of the century showed how achieved differentiations between mines and farmland, or resources and wastes, for example - could be dissolved and re-made in the struggle to assure the commerciality of Plateau tin. More broadly, the remarkable boom in Nigerian tin sheds light on the political, economic and cultural processes that transformed parts of the periphery into extractive economies in the late $19^{\text {th }}$ and early $20^{\text {th }}$ centuries, and which generated the 'increasing torrent of primary commodities flowing to the industrialized countries' at this time. ${ }^{84}$

\section{Acknowledgements}

This article presents research funded with the support of a Marie Curie Reintegration Grant from the European Commission (MIRG-CT-2006-039080). We thank two anonymous reviewers for their insightful and constructive comments, and Chris Sellers, Jo Melling and attendees at the 'Dangerous Trades' conference at Stony Brook University for extensive commentary on a much earlier version of this paper. We take full responsibility for the content, scope and interpretations provided in this paper. 


\section{Endnotes}

${ }^{1}$ Girouard, P. 1908. The Development of Northern Nigeria. Journal of the Royal African Society 7(28): 331-7.

${ }^{2}$ Calvert, A. F. 1912. Nigeria and its Tin Fields. London, Edward Stanford.

${ }^{3}$ Said, E. 1979, Orientalism. New York, Vintage Books; Pratt, M. 1992. Imperial Eyes: travel writing and transculturation, Routledge; McClintock, A. 1995. Imperial leather: race, gender and sexuality in the colonial context, Routledge; see also Blaut, J. 1993. The Colonizer's Model of the World: geographical diffusionism and Eurocentric history, Guilford Press..

${ }^{4}$ Harris, C. 2004. How did colonialism dispossess? Comments from an edge of Empire. Annals of the Association of American Geographers 94(1): 166.

5 'Erratic and exotic commodity' comes from Lang, quoted in Zimmerman, E. 1933 World Resources and Industries. New York, Harper Row, page 721, fn. 32: 'that it is exotic a glance at the world map showing tin production reveals clearly. Its erratic nature is in large part due to the organisation of the industry in which a considerable number of small entrepreneurs, especially large numbers of natives, play an important part.'

${ }^{6}$ Cramb, A. 2007. A Short History of Metals. Department of Materials Science and Engineering, Carnegie Mellon University. Available at http://neon.mems.cmu.edu/cramb/Processing/history.html. Accessed on November 12007

${ }^{7}$ Mumford, L. 1934. Technics and Civilization. Harcourt Brace and World.

${ }^{8}$ Hobsbawm, E. 1989. Age of Empire: 1875-1914. Vintage; Phimister, I. 2000. Corners and CompanyMongering: Nigerian Tin and the City of London 1909-1912. The Journal of Imperial and Commonwealth History 28(2): 23-41; Harvey, C. and J. Press 1990. The City and International Mining 1870-1914. Business History 32 (3): 98-119; see also Beckenbach, F. 1989. Social costs in modern capitalism. Capitalism, Nature, Socialism 1(3): 72-92.

${ }^{9}$ United States Geological Survey 1921 World Atlas of Commercial Geology, Washington D.C.; Naylor, S. 2000. Spacing the can: empire, modernity and the globalisation of food, Environment and Planning A 32: 1625-1639; see also Zimmerman 1933, 720.

${ }^{10}$ Shenton, B and B. Freund 1978. The incorporation of Northern Nigeria into the world capitalist economy. Review of African Political Economy 5: 13, 8-20.

${ }^{11}$ Grove, A. T. 1952. Land Use and Soil Conservation on the Jos Plateau. Geological Survey of Nigeria Bulletin No. 22, page 1 .

${ }^{12}$ Laws, H W (no date) Nigerian tin Mining Expedition: the personal narrative of HW Laws, CMG, DSO, MIMM who pioneered the expedition in 1903. MSS Afr Rhodes House, University of Oxford.

${ }^{13}$ Falconer, J. 1911. Geology and Geography of Northern Nigeria. MacMillan and Company, London, page 40.

${ }^{14}$ Laws, n.d. page 1.

${ }^{15}$ Johnson 1925, Laws n.d.

${ }^{16}$ Freund 1981: 35

${ }^{17}$ Nigerian black tin (cassiterite) may have been able to command a small premium: its relatively high grade meant it was used by Liverpool smelters to 'sweeten' batches of ore from Bolivia and Malaya.

${ }^{18}$ Young C. 1994. The African Colonial State in Comparative Perspective, New Haven, London, Yale University Press. 
${ }^{19}$ Scott, J. 1998. Seeing Like a State: how certain schemes to improve the human condition have failed. New Haven, CT: Yale University Press.

${ }^{20}$ Johnston 1925: 15; Phimister 2000)

${ }^{21}$ Calvert, 1910 p. 71

${ }^{22}$ Freund 1981: 37.

${ }^{23}$ Swyngedouw, E. 1999. Modernity and Hybridity: Nature, Regeneracionismo, and the Production of the Spanish Waterscape, 1890-1930. Annals of the Association of American Geographers 89 (3) 443-465; Gandy, M. 2002. Concrete and Clay: reworking nature in New York City. Cambridge: MIT Press; Kaika, M. 2005. City of Flows: Modernity, Nature, and the City. Routledge.

${ }^{24}$ For a classic statement, see Ashmead, E. 1909. Twenty-five Years of Mining, 1880-1904. London: Mining Journal.

25 Freund, W. 1981. Labour Migration to the Northern Nigerian Tin Mines, 1903-1945 Journal of African History 22(1): 73-84; Watts, M. 1983. Silent Violence: food, famine and peasantry in Northern Nigeria. Berkeley: University of California Press.

${ }^{26}$ Morrison, J. H. 1977. Early Tin Production and Nigerian Labour on the Jos Plateau 1906-21. Canadian Journal of African Studies 11 (2): 205-16; Dorward, D. 1987. The Impact of Colonialism on a Nigerian HillFarming Society: a case study of innovation among the Eggon,The International Journal of African Historical Studies 20(2): 215.

${ }^{27}$ Bower, P. 1947. The Mining Industry. In Mining, Commerce and Finance in Nigeria. Ed. M. Perham, Faber and Faber pp. 1-42; Grace, J. J. 1982. Tin Mining on the Plateau before 1920. In Studies in the History of Plateau State, Nigeria. E. Isichei (ed.) London and Basingstoke, Macmillan Press, page 184. Grace provides an account of how complaints by European miners that illegally mined tin was being smelted in the seven native furnaces at Liruien Delma (the only smelting site on the Plateau) led to the smelters being closed down in 1913.

${ }^{28}$ MSS Afr. 97 Vol 13, f. $115-33$

${ }^{29}$ Stafford, R. 1990 Annexing the landscapes of the past: British imperial geology in the nineteenth century. In Imperialism and the Natural World. Manchester, Manchester University Press. MacKenzie (ed.), page 74. Falconer's Survey of Northern Nigeria accords well with Michael Worboys' account of the role of imperial scientific surveys in the early $20^{\text {th }}$ century: it sought to 'remove ignorance, replace prejudice with facts and "open up" the colon(y) in a new way... Such activities both drew on and advanced the association of science and "systematic" measures with national efficiency, which was characteristic of social imperialism at this time.' Michael Worboys (1990) The Imperial Institute: the state and the development of the natural resources of the Colonial Empire, 1887-1923. In Imperialism and the Natural World, page 174.

${ }^{30}$ Braun 2000; Bonneuil 2000

${ }^{31}$ Phimister, I. 2000.

${ }^{32}$ Geary, W. 1927. Nigeria Under British Rule. London, Frank Cass; Medical Report 1912. Protectorate of Northern Nigeria Annual Medical Report, National Archives CO 657-1.

${ }^{33}$ Geary 1927, Nigeria Under British Rule, page 249

${ }^{34}$ Colonial Office 1917. Nigeria: Report on the Blue Book. National Archives, CO 657-4

${ }^{35}$ Data from Medical Report for 1912, page 6

${ }^{36}$ Bell, H. H. 1911. Recent Progress in Northern Nigeria. Journal of the Royal African Society 10(4): 377-91. 
${ }^{37}$ Health Report 1915 Colonial Office Sessional Papers, National Archives CO 657-4, page 12

${ }^{38}$ Health Report 1912, page 8. However, subsequent reports provide neither data nor discussion of health in the tin fields. Given that the Health Report's demographic variable of concern was the size of the European population, it would appear the focus was firmly on the British mining-related personnel who had been entering the Plateau in increasing numbers over the previous five years. By 1912, over a third of Europeans (250 out of 703) in the Protectorate were associated with mining.

${ }^{39}$ Although the 1912-14 drought was very severe in the Sahel, it appears that rainfall on the Plateau in 1913 was not as severely affected as further north (Hastings 1925, Grove 1973). Food shortages on the Plateau, therefore, were probably caused by the combination of harvest failure in the north combined with taxation-driven changes in land use both on and off the Plateau. We thank an anonymous reviewer for this observation.

${ }^{40}$ Freund, W. 1981. Capital and Labour in the Nigerian Tin Mines. London, Longman.

${ }^{41}$ Jones, W. R. 1925. Tin Fields of the World, cited in Fell, G. 1939. The Tin Mining Industry in Nigeria. Journal of the Royal African Society 38(151): 246-258.

${ }^{42}$ Mines Department 1919

${ }^{43}$ South African Mining and Engineering Journal 1943: 505

${ }^{44}$ Lush, F M. 1920. The Tin Deposits of Northern Nigeria. Mining Magazine 22: 334;

${ }^{45}$ Mines Department 1914, 1916.

${ }^{46}$ Lush, F M. 1920; Fell 1939: 250.

${ }^{47}$ Imperial Institute Bulletin 1907. Alluvial Tin Stone Deposits of Northern Nigeria. Volume 5, 179.

${ }^{48}$ Wallace, cited in Calvert 1912, Tin Fields of Nigeria, page 130.

${ }^{49}$ Laws n.d.

${ }^{50}$ Swindell, K. 1992. The struggle for transport labor in northern Nigeria, 1900-1912: a conflict of interest. African Economic History 20: 137-159.

${ }^{51}$ Grace 1982, Tin Mining on the Plateau

${ }^{52}$ Mining Magazine 1912. Tin Deposits in Northern Nigeria. March, 180.

${ }^{53}$ Bower 1947 The Mining Industry.

${ }^{54}$ Mines Department Report 1919 Annual Report on the Mines Department, Northern Provinces, for the Year 1919. Colonial Office Sessional Papers, National Archives CO 657-4

${ }^{55}$ Freund 1981, Capital and Labour; Freund and Shenton (1978: 15) indicate the average monthly employment in the mines was 39,000 in 1928.

${ }^{56}$ Mills, C. 2005. A Hazardous Bargain: occupational risk in Cornish Mining 1875-1914. Labour History Review 70(1): 53-71; Mills, C. 2008. The emergence of statutory hygiene precautions in the British Mining industries 1890-1914. The Historical Journal 51(1): 145-168.

${ }^{57}$ Basic working conditions in metal mines were initially regulated in the UK by the Metalliferous Mines Regulation Act of 1872 (following the findings of the Kinnaird Commission in 1864, which centred on poor ventilation and the condition known as phthisis, a form of silicosis). Subsequent studies of working conditions in the Cornish mines - including the Report on the Health of Cornish Miners in 1904 occasioned by an outbreak of hookworm at the large Dolcoath mine (Burke and Richardson 1978: The Profits of Death: A Comparative Study of Miners' Phthisis in Cornwall and the Transvaal, 1876-1918. Journal of Southern African Studies 4(2): 147171) - expanded the understanding of metal mining's occupational hazards to include sanitary conditions 
underground (Mills 2008). Many of these sanitary issues were undoubtedly a feature of labour-intensive, alluvial tin mining in west Africa: they do not, however, appear to have been officially recognised or studied by either the companies involved in Nigeria or the colonial administration.

${ }^{58}$ Cited in Swindell 1992, The Struggle for Transport, page 148.

${ }^{59}$ Morrison 1977, Early Tin Production

${ }^{60}$ Cited in Isichei E. 1982. Changes and Continuities 1906-1939. In Studies in the History of Plateau State, Nigeria. E. Isichei (ed.). London and Basingstoke, Macmillan Press, page 269.

${ }^{61}$ Mines Department 1916 Annual Report on the Mines Department, Northern Provinces, for the Year 1916. Colonial Office Sessional Papers, National Archives CO 657-4

${ }^{62}$ Freund 1981, Capital and Labour

${ }^{63}$ Colonial Office 1918. Nigeria: Report on the Blue Book. National Archives, CO 657-4

${ }^{64}$ Colonial Office 1918

${ }^{65}$ Alexander, M. 1990. Reclamation after Tin Mining on the Jos Plateau. The Geographical Journal 156 (1): $44-$ 50 .

${ }^{66}$ Kirk-Greene A. H. 1961. Kitty Cooke Looks Back: a Personal Mining Memoir, Nigerian Field XXXVI.

${ }^{67}$ See also Silver, J. 1981 The Failure of European Mining Companies in the 19th century Gold Coast. The Journal of African History 22(4): 511-529.

${ }^{68}$ This appears to have been a process of supplementation rather than replacement, not least because tribute miners - those not under the employ of mines but which worked tin on their own account and sold it to the mines - continued to be very active. Grove (1952) Land Use and Soil Conservation indicates that "tributers and dailypaid workers have mined between one half and two-thirds of the total yardage on the Plateau during the past 10 years...there is little prospect of restoring the land which they have disturbed"

${ }^{69}$ Topographical details in this paragraph draw on Alexander (1990) Reclamation after Tin Mining, who also shows how subsequent attempts to re-vegetate these mounds have been hampered by the fact that dragline operations did not use the phased (topsoil, subsoil, overburden) removal system: 'excavation involved the simultaneous removal of all three materials, with the result that the spoil mounds comprised a melange of these strata, thus creating considerable difficulties for any attempts at reclamation' (page 45).

${ }^{70} \mathrm{CO}-879-105$, page 1.

${ }^{71}$ Evidence from other settings also shows how mineral development could cause alarm and consternation among colonial administrators on account of its effect on the cost and availability of labour, and the disruptive political effects it could produce (see, for example, Stafford 1990, page 74 on the discovery of gold in New South Wales).

${ }^{72}$ The Resident (Colonial Government Official) at Nasarawa noted in 1914 that 'the great difficulty with which we have to contend in our endeavours to make Wanba market large and prosperous is, of course, the existence of the mining community in the neighbourhood. The Europeans connected with mining seem as a rule to be better paid than Government Officials and their native employees are also better paid than ours...' National Archives CO 959/2: Records of Henry Lionel Norton Traill.

\footnotetext{
${ }^{73}$ We use the term 'armoury' here for two reasons: practices of colonial state building in Africa - including those of geological science - were centuries in the making, and based on experiences and tools honed in settings like India and the Caribbean (e.g. Harris, S. 1998 Long-distance corporations, big sciences, and the geography of knowledge. Configurations, 6(2) 269-304); and, as a military metaphor, it captures the centrality of violence and dispossession to the colonial enterprise (Harris, C. 2004 How did colonialism dispossess?).
} 
${ }^{74}$ Grove 1952, Land Use and Soil Conservation

${ }^{75}$ Phillips-Howard, K., and F. Lyon. 1994. Agricultural Intensification and the Threat to Soil Fertility in Africa: evidence from the Jos Plateau, Nigeria. The Geographical Journal 160(5): 252-65; Milligan, S, and T. Binns. 2007. Crisis in policy, policy in crisis: understanding environmental discourse and resource-use conflict in northern Nigeria. The Geographical Journal 173 (2): 143-156.

${ }^{76}$ Geological Survey of Nigeria 1930.

${ }^{77}$ Grove 1952, Land Use and Soil Conservation, page 51

${ }^{78}$ Grove 1952, Land Use and Soil Conservation, page 33

${ }^{79}$ See also Bonneuil, C. 2000. Development as Experiment: science and state building in Late Colonial and Postcolonial Africa, 1930-1970. Osiris 15: 258-81

${ }^{80}$ Grove 1952, Land Use and Soil Conservation, page 34.

${ }^{81}$ Alexander, M. J. and A. D. Kidd 2000. Farmers' capability and institutional incapacity in reclaiming disturbed land on the Jos Plateau, Nigeria. Journal of Environmental Management 59(2), page 145.

${ }^{82}$ Pasquini, M., and M. Alexander. 2005. Soil Fertility Management Strategies on the Jos Plateau: the need for integrating 'empirical' and 'scientific' knowledge in agricultural development. The Geographical Journal 171 (2): $112-24$.

${ }^{83}$ Ibeanu, I. 2003. Tin mining and processing in Nigeria: cause for concern? Journal of Environmental Radioactivity 64: 59-66

${ }^{84}$ Schmitz, C. 1979. World Non-ferrous Metal Production and Prices. 1700-1976. New York, Routledge, page 28. 